\title{
Exclosures restored the density and root colonization of arbuscular mycorrhizal fungi in Tigray, Northern Ethiopia
}

\author{
Emiru Birhane ${ }^{1,2^{*}}$ DD, Kide Mogos Gebremedihin ${ }^{1}$, Tewodros Tadesse ${ }^{3}$, Mengsteab Hailemariam ${ }^{1}$ \\ and Negasi Solomon ${ }^{1}$
}

\begin{abstract}
Introduction: Exclusion of grazing animals and tree plantations were among the methods used for the restoration of degraded lands in tropical semiarid areas. Exclosures can foster secondary forest succession by improving soil conditions and modifying microclimate for understory growth. This paper compared the arbuscular mycorrhizal fungi (AMF) spore density, root colonization of woody plants and soil chemical properties under exclosure with increasing age, and grazing land at different slope positions.

Methods: The study was conducted in northern Ethiopia from 12 exclosure sites paired each with adjacent grazing land in total from 24 sites with four treatments replicated three times. In the entire study, 216 plots were examined of which 108 were in exclosures and 108 in communal grazing lands. There were four age classes and three slope positions in each of the land uses. Composite soil and root samples were collected using nested plots measuring $100 \mathrm{~m}^{2}$ from four sides of 1763 plants for spore enumeration and root colonization. Soils for chemical properties were collected from the four corners and center of $5 \mathrm{~m} \times 5 \mathrm{~m}$ plots.

Results: All the 61 woody plant species that belong to 41 families were colonized by AMF. Spore density and root colonization were significantly higher in exclosures as compared to grazing land and increased with increasing ages of exclosures. Foot slope had significantly higher spore density and root colonization than middle and upper slopes. Soil chemical properties were significantly higher in the exclosure, oldest age of exclosure, and foot slope position (except P). AMF spore density and root colonization were significantly positively correlated with soil chemical properties.
\end{abstract}

Conclusions: Exclosures are helpful to restore the AMF spore density and root colonization of woody species and soil fertility.

Keywords: Spore density, Root colonization, Age of exclosure, Slope position

\section{Introduction}

Exclosures are areas closed off from the interference of human and domestic animals with the goal of promoting natural regeneration of plants and reducing land degradation of formerly degraded communal grazing lands (Nedessa et al. 2005). They are usually established in steep, eroded, and degraded areas that have been used for

\footnotetext{
* Correspondence: emiru.birhane@mu.edu.et; emiru.birhane.hizikiaz@nmbu.edu.et

'Department of Land Resources Management and Environmental protection, Mekelle University, PO Box 231, Mekelle, Ethiopia

${ }^{2}$ Faculty of Environmental Sciences and Natural Resource Management, Norwegian University of Life Sciences, PO Box 5003, 1432 Ås, Norway Full list of author information is available at the end of the article
}

grazing in the past (Descheemaeker et al. 2006a, b). In Ethiopia, the inception of exclosures dates back to the 1980s and coincided with the introduction of large-scale land rehabilitation and soil and water conservation program (Nedessa et al. 2005). The main objective of establishing exclosures on communal grazing lands is to improve the overall ecological conditions of the degraded areas so that they can provide better environmental and socioeconomic benefits to the local communities. Several case studies have reported beneficial effects of exclosures: natural vegetation has regenerated, runoff, and sheet and rill erosion are reduced, the land is stabilized, water availability has increased, and soil physical and chemical 
properties are improved (Girmay et al. 2009; Mekuria et al. 2009; Mekuria et al. 2007; Yami et al. 2007; Descheemaeker et al. 2006a, b). These positive consequences are also noticed and appreciated by the local communities (Mekuria et al. 2009).

The impact of grazing on soil properties depends on grazing management, the non-grazed control site provided higher soil $\mathrm{pH}$, available $\mathrm{P}$, and $\mathrm{Mg}$ compared with moderately grazed site of 33 years old (Ajorlo et al. 2011). Available phosphorus (P), total nitrogen $(\mathrm{N})$, calcium $(\mathrm{Ca})$, magnesium $(\mathrm{Mg})$, and potassium $(\mathrm{K})$ decreased after 1.5 years of open grazing compared with an ungrazed control in a tropical pasture (Ajorlo et al. 2011). In addition, open grazing resulted in lower water infiltration (Hiernaux et al. 1999) and higher soil loss (Tadesse and Penden 2002) compared with moderately grazed sites. Exclosures with 12 years old enhance the total plant cover, dry matter yield, species richness, and contents of soil organic matter, total nitrogen, and water infiltration rate compared with continually grazed area (Jeddi and Chaieb 2010). Exclusion of livestock grazing for 20 years significantly increased aboveground and belowground biomass and species richness for five different communities compared with non exclosed sites in Loess Plateau, northwest China (Cheng et al. 2011). The exclosures had twice more plant species richness and diversity value as compared with communal grazing lands after 22 years of exclosure establishment in the central and northern highlands of Ethiopia (Mengistu et al. 2005). There were increases in the number of woody species richness after 8 years of exclosure establishment (Birhane et al. 2006), 1.1\% increase in soil organic matter, $0.1 \%$ in total $\mathrm{N}, 1.8 \mathrm{mg} \mathrm{kg}^{-1}$ in available $\mathrm{P}$ increase after 10 years of exclosure establishment (Mekuria et al. 2007). A considerable decrease in soil loss was reported after the establishment of exclosures on communal grazing lands (Girmay et al. 2009; Mekuria et al. 2009; Descheemaeker et al. 2006a, b). Exclosures have been reported to positively contribute to restore soil biological properties such as arbuscular mycorrhizal fungi (Birhane et al. 2010).

Arbuscular mycorrhizal fungi (AMF) colonize about $80 \%$ of plants (Wang and Zao 2008) and they are regular component of rhizosphere micro-flora in natural ecosystem (Sharma et al. 2009). AMF form obligate symbiotic association with many tropical plants (Manoharachary et al. 2005). The function of AMF in exclusion process and knowledge of AMF diversity in a specific area is essencial to utilize AMF in any application (Wang and Zao 2008). The very few conditions where infective AMF are low in density and diversity is when the soil erodes, is disturbed, and is devoid of vegetation cover (Asmelash et al. 2016). The presence of enough AMF propagules in a restored site facilitates the establishment of plant communities through increased availability of nutrients and moisture to plant roots (Asmelash et al. 2016). Though exclosures positively contributed to land rehabilitation, there are limited studies on the role of exclosures to restore arbuscular mycorrhizal fungi. There is a limited study that attempted to understand the role of exclosure in the restoration of AMF with increasing age of exclosures at different slope positions during the rainy season. The slope position significantly affects the density of spores found in a given landscape. The spore density was found to be higher from exclosures of middle slope position in the dry season (Birhane et al. 2017). We investigated the spore density in the soils and woody plant root colonization of AMF from paired exclosure and adjacent grazing land with increasing age of exclosures at the foot, middle, and upper slope hillsides. The correlation between the availability of soil nutrients with AMF spore density and root colonization was assessed. We aimed to answer the following questions: What is the dynamics of AMF with increasing age exclosures at different slope positions? Does the availability of nutrients correlated with AMF spore density and root colonization? And does the increase in the age of exclosures increased the availability of nutrients at different slope positions?

\section{Methods}

\section{Study area}

The study was conducted in the highlands of Tigray region, Northern Ethiopia in 12 sites representing four zones and four districts (Table 1). All sites have tropical semi-arid climate. The altitude of the study sites ranged from 2232 to 2937 m.a.s.l. The rainy season usually occurs between June and September (Fig. 1), and the growing season varies between 90 and 120 days. The highest rainfall is in July and August which ranges between 162 and $228 \mathrm{~mm}$. The temperature of the study sites ranges from 19 to $30{ }^{\circ} \mathrm{C}$, the maximum is recorded in the months of May and June (Fig. 1).

Luvisols (Alfisols), Regosols (Entisols), Cambisols (Inceptisols), and Calcisols (Aridisols) were major soil groups in the study area (WRB 2006). The 24 study sites were dominanted by Luvisols (Alfisols) and Cambisols (Inceptisols). Acacia etbaica, Acacia seyal (Del.), Becium grandiflorum (Lam.) Pichi-Serm., Euclea racemosa subsp. schimperi (A. DC.) Dandy, and Maytenus arbutifolia (Hochst. ex. A. Rich) Wilczek were the woody vegetation species common in exclosures and adjacent grazing lands (Mekuria 2010).

Mixed farming system that integrates crop and livestock was the main means of livelihood. The major land uses were cultivated land, forest land, exclosure, and communal grazing land (Mekuria 2010). The main crops cultivated were Teff (Eragrostis teff (Zucc.) Trotter), 
Table 1 Specific study site age, altitude and geographic location

\begin{tabular}{|c|c|c|c|c|c|}
\hline Specific site & Zone & District & Age (year) & Altitude $(\mathrm{m})$ & Geographic location \\
\hline Adihintaweinai & East & Atsbi wonberta & $<10$ & $2201-2312$ & $\begin{array}{l}39^{\circ} 38^{\prime} 60^{\prime \prime}-39^{\circ} 50^{\prime} 52^{\prime \prime} \text { East } \\
13^{\circ} 12^{\prime} 75^{\prime \prime}-14^{\circ} 4^{\prime} 41^{\prime \prime} \text { North }\end{array}$ \\
\hline Halla & Southeast & Degua Tembien & $<10$ & 2232-2937 & $\begin{array}{l}38^{\circ} 30^{\prime} 17^{\prime \prime}-38^{\circ} 40^{\prime} 57^{\prime \prime} \text { East } \\
13^{\circ} 54^{\prime} 3^{\prime \prime}-14^{\circ} 20^{\prime} 30^{\prime \prime} \text { North }\end{array}$ \\
\hline Melgim & East & Atsbi wonberta & $<10$ & $2264-2343$ & $\begin{array}{l}39^{\circ} 38^{\prime} 60^{\prime \prime}-39^{\circ} 50^{\prime} 52^{\prime \prime} \text { East } \\
13^{\circ} 12^{\prime} 75^{\prime \prime}-14^{\circ} 4^{\prime} 41^{\prime \prime} \text { North }\end{array}$ \\
\hline Endagebriel & East & Atsbi wonberta & $10-20$ & $2248-2351$ & $\begin{array}{l}39^{\circ} 38^{\prime} 60^{\prime \prime}-39^{\circ} 50^{\prime} 52^{\prime \prime} \text { East } \\
13^{\circ} 12^{\prime} 75^{\prime \prime}-14^{\circ} 4^{\prime} 41^{\prime \prime} \text { North }\end{array}$ \\
\hline Gurzoemni & Central & Tahtay Maichew & $10-20$ & $2244-2322$ & $\begin{array}{l}38^{\circ} 30^{\prime} 17^{\prime \prime}-38^{\circ} 40^{\prime} 57^{\prime \prime} \text { East } \\
13^{\circ} 54^{\prime} 3^{\prime \prime}-14^{\circ} 20^{\prime} 30^{\prime \prime} \text { North }\end{array}$ \\
\hline Mezewle & East & Atsbi wonberta & $10-20$ & $2325-2411$ & $\begin{array}{l}39^{\circ} 38^{\prime} 60^{\prime \prime}-39^{\circ} 50^{\prime} 52^{\prime \prime} \text { East } \\
13^{\circ} 54^{\prime} 3^{\prime \prime}-14^{\circ} 20^{\prime} 30^{\prime \prime} \text { North }\end{array}$ \\
\hline Adikolakul & Southeast & Degua Tembien & $20-30$ & $2180-2214$ & $\begin{array}{l}38^{\circ} 30^{\prime} 17^{\prime \prime}-38^{\circ} 40^{\prime} 57^{\prime \prime} \text { East } \\
13^{\circ} 54^{\prime} 3^{\prime \prime}-14^{\circ} 20^{\prime} 30^{\prime \prime} \text { North }\end{array}$ \\
\hline Suhulkoma & East & Atsbi wonberta & $20-30$ & $2295-2347$ & $\begin{array}{l}39^{\circ} 38^{\prime} 60^{\prime \prime}-39^{\circ} 50^{\prime} 52^{\prime \prime} \text { East } \\
13^{\circ} 12^{\prime} 75^{\prime \prime}-14^{\circ} 4^{\prime} 41^{\prime \prime} \text { North }\end{array}$ \\
\hline Wereriba & Southeast & Doguetembien & $20-30$ & $2200-2358$ & $\begin{array}{l}13^{\circ} 16^{\prime} 23^{\prime \prime}-13,047^{\prime} 44^{\prime \prime} \text { East } \\
39^{\circ} 3^{\prime} 17^{\prime \prime}-39,024^{\prime} 48^{\prime \prime} \text { North }\end{array}$ \\
\hline Gratselim & Southeast & Degua Tembien & $30-40$ & $2369-2458$ & $\begin{array}{l}38^{\circ} 30^{\prime} 17^{\prime \prime}-38^{\circ} 40^{\prime} 57^{\prime \prime} \text { East } \\
13^{\circ} 54^{\prime} 3^{\prime \prime}-14^{\circ} 20^{\prime} 30^{\prime \prime} \text { North }\end{array}$ \\
\hline Kerenadidemsash & South & Endamekoni & $30-40$ & $2314-2419$ & $\begin{array}{l}39^{\circ} 16^{\prime} 52^{\prime \prime}-39^{\circ} 35^{\prime} 31^{\prime \prime} \text { East } \\
12^{\circ} 38^{\prime} 4^{\prime \prime}-12^{\circ} 51^{\prime} 39^{\prime \prime} \text { North }\end{array}$ \\
\hline Maibiati & Southeast & Degua Tembien & $30-40$ & $2358-2429$ & $\begin{array}{l}38^{\circ} 30^{\prime} 17^{\prime \prime}-38^{\circ} 40^{\prime} 57^{\prime \prime} \text { East } \\
13^{\circ} 54^{\prime} 3^{\prime \prime}-14^{\circ} 20^{\prime} 30^{\prime \prime} \text { North }\end{array}$ \\
\hline
\end{tabular}

Bread wheat (Triticum aestivum), Maize (Zea mays L.), Sorghum (Sorghum bicolor), Barley (Hordeum vulgare), and Faba bean (Vicia faba). The main animal which graze the communal grazing lands were cattle, goats, sheep, donkeys, camel, mule, and horse.

\section{Experimental design}

The age of restoration, slope position, and land use effect on AMF spore density, woody plant root colonization, and soil chemical properties were studied from 12 exclosure sites paired each with adjacent grazing land during the dry season. The distance between the exclosure and the adjacent grazing land was in the range of 50 to $100 \mathrm{~m}$. There were four age classes and three slope positions in each of the land uses. The first age group had less than 10 years old exclosure with triplicate sites (Halla, Meligim, and Adihantaweynay), the second age group was 10 to 20 years old exclosure with triplicate sites (Gurzoemni, Mezewle, and Endagebriel), and the third age group had 20 to 30 years old exclosure with triplicates

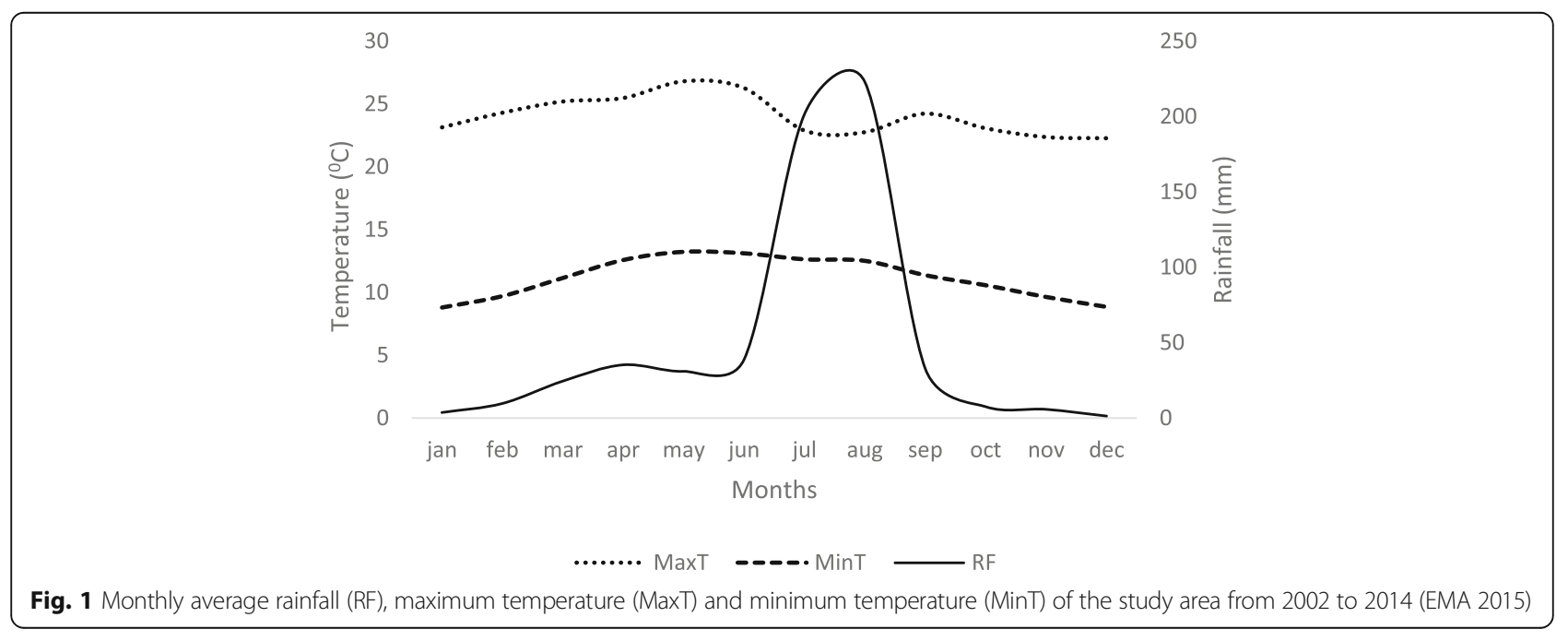


sites (Addikolakul, Wereriba, and Shul-koma). The fourth group had greater than 30 years old exclosure with triplicate sites (Maybe'ati, Kerenadidemsash, and Gratselim). The assumption were prior to establishment, exclosures and the adjacent grazing lands had similar biophysical, socioeconomic, and management conditions as the exclosures were established on the same communal grazing lands which were used for livestock grazing (Mekuria 2010). The experiment was composed of 12 experimental units with four treatments replicated three times. Site had two levels (closed and open), age with four levels $(<10$, $10-20,20-30$, and $>30$ years old) with three slope positions (upper, middle, and foot slope). In the entire study, 216 plots $(12 \times 3$ small plots $\times 3$ slope positions $\times 2$ pair exclosure and adjacent grazing land) were examined of which 108 were in exclosures and 108 in communal grazing lands. The small plots used to collect soil samples. In each exclosure and grazing land randomly established three transects spaced at a minimum distance of $75 \mathrm{~m}$ (Mekuria 2010).

The number of transects were based on vegetation density, spatial heterogeneity of vegetation, and area of the site. The area of the selected exclosures ranged from 7 to 85 ha, whereas that of the adjacent communal grazing lands ranged from 2 to 38 ha. To avoid edge effects, the first transect was laid $30-50 \mathrm{~m}$ inside the exclosures and grazing lands. Transects were parallel to each other and to the topography of the landscape. In each transect, three slope positions (upper slope (US), mid slope (MS), and foot slope (FS)) were delineated and in each landscape position, a sampling plot measuring $10 \mathrm{~m} \times 10 \mathrm{~m}$ was established. In each plot, $5 \mathrm{~m} \times 5 \mathrm{~m}$ subplots for soil physical and chemical analysis were developed. The US position is the uppermost portion of each study site, and it can receive little or no overland flow but may contribute runoff to down slope areas. The MS position receives overland flow from the upper slope and contributes runoff to the FS. The FS represents the lowest part of each study site and receives overland flow from both mid and upper slopes.

\section{Plant and soil sampling methods}

The plant roots and soils were sampled during the dry season from October 2013 to January 2014 for a total of 4 months from exclosures and adjacent surrounding grazing lands. All woody plants were sampled from the $10 \mathrm{~m} \times 10 \mathrm{~m}$ quadrates $\left(100 \mathrm{~m}^{2}\right)$ for trees and shrubs from both land uses. Woody plants were replicated three times in each plot. Composite soil and root samples were collected for spore density and root colonization from a total of 1763 samples from 4 sides of each plant found in each plot from the exclosures and adjacent grazing lands. The identity of the plant was identified at the field and verified using reference books such as
Bekele (2007), Inga et al. (2003), Sue et al. (1995, 2000), and Inga and Sue (1989).

Soil samples were collected from $5 \mathrm{~m} \times 5 \mathrm{~m}$ subplots nested with in the $10 \mathrm{~m} \times 10 \mathrm{~m}$ at the center of the main plots. A total of 216 soil samples were collected. The soil samples for one plot was taken from the four corners and the center of a square plot at $0-50 \mathrm{~cm}$ soil depths following an " $\mathrm{X}$ " pattern of the main plot to form one composite sample in order to determine texture, soil organic carbon, $\mathrm{pH}, \mathrm{EC}, \mathrm{N}, \mathrm{K}$, and $\mathrm{P}$ in exclosures and adjacent grazing lands. The five soil samples measured $300 \mathrm{~g}$ each were mixed and form $1500 \mathrm{~g}$ in total and make single composite sample to represent the sample plot. From the composite sample, $1 \mathrm{~kg}$ soil was taken and was put into plastic bags, secured, labeled and brought to the soil laboratory. Soil samples were analyzed for $\mathrm{pH}$ and electrical conductivity on 1:2.5, soil: water suspension method. Organic matter was analyzed using the Walkley-Black method (Van Ranset et al. 1999), total nitrogen content by the Kjeldahl method (Bremmery and Mulvaney 1982). Available potassium and texture were analyzed with flame spectrophotometer and hydrometer method (Gee and Bauder 1982). Available P determined using the Olson method (Olsen and Sommers 1982).

\section{AMF root length colonization and spore density sampling}

Root samples of all plants were collected by excavating soil using a handheld hoe starting from the plant's trunk base in four directions of the plant and working out towards to get fine roots within $3-5 \mathrm{~m}$ radius. Forty-gram root samples from all four directions were collected from 0 to $30 \mathrm{~cm}$ depth, mixed and then $10 \mathrm{~g}$ fine roots (diameter $<2 \mathrm{~mm}$ ) were taken from the composite root samples. The collected fine roots were put into beaker and carefully washed with tap water until the soil was removed and became free of any soil particles and put into plastic jar and filled with $97 \%$ ethanol to preserve the roots until they were ready for processing. Soil samples were taken at $50 \mathrm{~cm}$ depth using auger (Chanie and Assefa 2013) in four directions of each plant and gave $300 \mathrm{~g}$ soil sample, in total $1200 \mathrm{~g}$ soil sample were mixed to make one composite soil sample. For each plant, $1 \mathrm{~kg}$ composite soil samples was taken from the $1200 \mathrm{~g}$ of soil and put in a sealed plastic bag. The sampled roots and soils were transported to Mekelle University laboratory for estimating root colonization and spore extraction.

AMF spores were separated from the soil by the wet sieving and 50\% sucrose centrifugation method (Brundrett et al. 1996). For spore extraction, the soils first airdried and pass through $0.75 \mathrm{~mm}$ sieve and weighed using sensitive balance to get a subsample of $25 \mathrm{~g}$. The weighed dry soil was wet with enough amount of water for at least $30 \mathrm{~min}$. The wet soil was stirred for 15 to 
$30 \mathrm{~min}$ and then decanted through a series of sieves by putting in ascending order with the smallest sieve size $(50 \mu \mathrm{m})$ at the bottom, followed by 100,300 , and $750 \mu \mathrm{m}$ sieve size at the upper most. The $750 \mu \mathrm{m}$ sieve size used to remove unnecessary materials. The different sieve sizes were given codes as $50 \mu \mathrm{m}=\mathrm{A}, 100 \mu \mathrm{m}=\mathrm{B}$, and $300 \mu \mathrm{m}=\mathrm{C}$, to designate the spore sizes captured by each sieve sizes. Spores were counted from $25 \mathrm{~g}$ soil using dissecting microscope with $\times 100$ magnification.

AMF spores were grouped into genera using their morphological characteristics such as spore size, shape, color, wall structure, and hyphal attachment (simple, swollen, or bulbous). Permanent slides were prepared for each different spore morphotype with polyvinyl alcohol plus Melzer's solution. The PVLG mountant was prepared using polyvinyl alcohol $8.33 \mathrm{~g}$ (polyvinyl alcohol should be used and can be dissolved in water by heating at $90{ }^{\circ} \mathrm{C}$ overnight), distilled water $50 \mathrm{ml}$, lactic acid $50 \mathrm{ml}$, and glycerin $5 \mathrm{ml}$ ) and prepared Melzer's reagent (1.5 g iodine, $5 \mathrm{~g}$ potassium iodide, and $100 \mathrm{ml}$ distilled water). The Melzer's reagent then mixed 1:1 $(v / v)$ with PVLG (Brundrett et al. 1996). Small droplets of the mountant was added using pipet (1:1 PVLG and Melzer's reagent) on to the microscope slide then the spores put on it using paint brush and pressed with coverslip to easily see and identify the internal structures of the spores. The genera of each spore were identified using a compound microscope with $\times 400$ magnification based on descriptions in Brundrett et al. (1996) and information from the INVAM website (http://www.invam.caf.wvu.edu).

The procedure in Brundrett et al. (1996) was used to determine root colonization. To identify root colonization, the roots were washed to remove ethanol, cut into $1 \mathrm{~cm}$ length, and insert into the heat resistant bottle containing $10 \% \mathrm{KOH}$ solution then autoclaved for $20 \mathrm{~min}$ at $120{ }^{\circ} \mathrm{C}$. The roots were washed to remove $\mathrm{KOH}$ and put into $10 \%$ $\mathrm{H}_{2} \mathrm{O}_{2}$ for further bleaching and clearing for about $15 \mathrm{~min}$. Cleared roots were captured on a fine sieve and rinsed with water before transferring them into the $\mathrm{HCl}$ solution. Roots were acidified with $3 \% \mathrm{HCl}$ for about $30 \mathrm{~min}$ and stained in trypan blue $(0.05 \%$ in 5:1:1 lactic acid: glycerol: distilled water) over night. The stained roots were washed and added to $50 \%$ glycerol for destaining and preserved until further processing. Then roots were prepared on slide lengthwise by selecting 20 subsample roots. The proportional root colonization by AMF was estimated using the magnified intersection method with hair line graticule inserted into an eyepiece acted as the line of intersection with each root at 400 magnification power under the compound microscope. Percentage of root length colonization (RLC \%) was calculated from 100 or more intersections for each root sample. At each intersection, there were six possible mutually exclusive outcomes (Brundrett et al. 1994).

\section{Statistical analyses}

The differences in spore density, root colonization, and soil parameters between an exclosure and its adjacent communal grazing land at different age groups and landscape position were assessed using two- and three-way ANOVA with Tukey HSD test after checking normality test. Pearson correlation test was used to conduct relationships between spore density and root colonization and soil parameters. Statistical package for social sciences (SPSS) version 20 was used to analyze spore density and root colonization of AMF and the soil.

\section{Results and discussion}

AMF spore density and root colonization between exclosures and adjacent grazing lands

Six AMF genera were recovered and identified in exclosures (Table 2). Glomus was the dominant genus found in all soils followed by Acaulospora, Gigaspora, Scutellospora, Entrophospora, and Sclerocystis. Glomus, Acaulospora, and Gigaspora were found in all the 12 sites followed by Scutellospora (11), Entrophospora (9), and Sclerocystis (1). This finding was similar to Vyas and Gupta (2014) where they found similar dominance order of genera. Exclosures had significantly higher spore density (4385 spores $100 \mathrm{~g}^{-1}$ dry soil and 6 genera) than grazing land (176 spores $100 \mathrm{~g}^{-1}$ dry soil and 5 genera). The genus Sclerocystis was retrieved from exclosure but not in the samples from grazing land.

Exclosures had higher spore density mainly dominated by the genus Glomus in Northern Ethiopia (Birhane et al. 2010). The low spore density in grazing land could be due to high soil disturbance, changes in land use and management, and changes in plant community composition (Birhane et al. 2017; Santos-González et al. 2007).

The spore density recovered in this study was higher than the total number of spores recovered from forest and grazing land (Chris 2010). Glomus was the most dominant genus in exclosure and in grazing land. Glomus is a predominantly genus found to be distributed in soils all over the world (Minal and Anil 2012; Chris 2010) and is the dominant genus in disturbed soils (Tanvir et al. 2011;

Table 2 Spore density and spore genera in exclosures and grazing land ( $100 \mathrm{~g}^{-1}$ dry soil)

\begin{tabular}{llllllll}
\hline LU & Gigaspora & Scutellospora & Glomus & Sclerocystis & Acaulospora & Entrophospora & Sum \\
\hline EX & $206.3 \pm 5.5 \mathrm{a}$ & $105.2 \pm 3.3 \mathrm{a}$ & $2468.2 \pm 42.2 \mathrm{a}$ & $0.013 \pm .009 \mathrm{a}$ & $1582.2 \pm 30.8 \mathrm{a}$ & $23.2 \pm 1.3 \mathrm{a}$ & $4385.3 \pm 80.4 \mathrm{a}$ \\
$\mathrm{GL}$ & $2.3 \pm 8.5 \mathrm{~b}$ & $0.271 \pm 5.1 \mathrm{~b}$ & $110.2 \pm 64.3 \mathrm{~b}$ & $0.000 \pm .013 \mathrm{a}$ & $63.3 \pm 47.0 \mathrm{~b}$ & $0.068 \pm 1.9 \mathrm{~b}$ & $176.3 \pm 122.5 \mathrm{~b}$ \\
\hline
\end{tabular}

Means followed by the same letter in the same column are not significantly different at $P<0.05$ level, mean \pm SEM

$G L$ grazing land, EX exclosure, $L U$ land use types 
Table 3 Root length colonization (\%) of AMF between exclosures and open grazing lands

\begin{tabular}{lllll}
\hline Land use types & $H C$ & MHC & AC & VC \\
\hline Exclosure & $78.4 \pm 0.4 \mathrm{a}$ & $70.1 \pm 0.5 \mathrm{a}$ & $50.3 \pm 0.5 \mathrm{a}$ & $38.1 \pm 0.5 \mathrm{a}$ \\
Grazing land & $55.7 \pm 0.6 \mathrm{~b}$ & $47.5 \pm 0.8 \mathrm{~b}$ & $35.5 \pm 0.8 \mathrm{~b}$ & $23.4 \pm 0.8 \mathrm{~b}$
\end{tabular}

Means in the same column followed by same letter do not differ significantly at $P<0.05$, mean $\pm \mathrm{SEM}$

$H C$ hyphal colonization, $M H C$ mycorrhizal colonization, $A C$ arbuscular colonization, $V C$ vesicular colonization

Burni et al. 2009; Sharma et al. 2009; Wang and Zao 2008; Mridha and Dhar 2007; Panwar and Tarafdar 2006; Burni and Illahi 2004). The predominance of Glomus species under varying soil conditions might be due to its wide adaptability to the varied soil conditions and survive in acidic as well as in alkaline soils (Tanvir et al. 2011; Pande and Tarafdar 2004).

Spore density in undisturbed natural environment is higher than disturbed sites (Chanie and Assefa 2013; Muleta et al. 2008). AMF plays a role in the formation of stable soil aggregates, building up a macroporous structure of soil that allows penetration of water and air and prevents erosion (Rillig 2004; Borie et al. 2008; Aggarwal et al. 2011); therefore, the application of AMF is of interest for the reclamation and revegetation of degraded lands (Miller and Jastrow 1992).

The influence of grazing on soil nutrient availability and host plant productivity (Frank and McNaughton 1993) may cause variable effects on AMF community composition and structure (Bai et al. 2013; Eom et al. 2001). Grazing intensity might change the level of mycorrhizal infection in a community by altering the plant composition and is an important factor in regulating the cycling of nutrients in undisturbed ecosystems (Abbott and Robson 1991). Grazing can influence the dynamics of nutrient exchange between host plants and AMF (Gehring and Whitham 2002). Herbivore grazing can alter leaf photosynthetic rates (McNaughton 1979), the above ground production (Frank and McNaughton 1993) and the C allocation below ground (Frank et al. 2002). The allocation of AMF morphological structures can either increase or decrease depending on the timing and severity of herbivores (Gange 2007).

Land use significantly affected AMF root colonization (Table 3). AMF root colonization was significantly higher in exclosures compared to the adjacent grazing land $(P<0.05)$. Hyphal colonization was the highest followed by $\mathrm{MHC}$ and $\mathrm{AC}$ while the least was VC. The grazing land showed low root colonization, and the higher colonization was for hyphae followed by $\mathrm{MHC}, \mathrm{AC}$, and $\mathrm{VC}$, respectively.

\section{AMF spore density and root colonization with increasing age of exclosures and slope position}

Spore density increased significantly as the age of exclosure increased $(P<0.05)$. An exclosure with greater than 30 age class counted higher spore density followed by age class between 20 and 30, age class between 10 and 20 , and age class less than 10, respectively (Table 4). AMF spore density ranged from 25 to 2550 in $100 \mathrm{~g}^{-1}$ of dry soil with increasing stability of ecosystem (Zhao et al. 2003). High AMF diversity was found in undisturbed and old woodlands and forests (Don-Rodrigue et al. 2013; Mathimaran et al. 2007; Muthukumar and Udaiyan 2000; Wilson et al. 1992). Glomus, Acaulospora, and Gigaspora were highly significantly different in all age classes while Scutellospora and Entrophospora significantly differed only among age classes greater than 30, age class from 20 to 30, and 10-20 (Table 4). Except Sclerocystis and Entrophospora, all the genera were found in all age classes. The dominant genera at all stages of wheat crop development were Acaulospora, Glomus, and Scutellospora (Arpita et al. 2012; Schalamuk et al. 2006) and the dominant genera in tropical rainforest were Acaulospora and Glomus (Zhao et al. 2003). The increased trend in spore density with increased age of exclosures is related to the low disturbance and high organic matter in old age exclosure (Burni and Ilahi 2004; Anwar and Jalaluddin 1991). High organic matter increases the water holding capacity of soil which may enhance the sporulation of AMF.

All AMF genera showed significant difference between slope positions except for Sclerocystis (Table 5). The foot and middle slope had six genera whereas the upper slope had five genera (Table 5). The highest spore density was recorded at the foot slopes followed by the middle and upper slopes. The interactions between age $\times$ land use, age $\times$ elevation, land use $\times$ elevation, and age $\times$ land use $\times$ elevation also showed significant difference in spore density $(P=0.000)$. This high spore density and genera

Table 4 AMF spore density and spore genera in four age classes of exclosures ( $100 \mathrm{~g}^{-1}$ of dry soil)

\begin{tabular}{llllllll}
\hline Age (year) & Gigaspora & Scutellospora & Glomus & Sclerocystis & Acaulospora & Entrophospora & Sum \\
\hline$<10$ & $6.1 \pm 10.6 \mathrm{~d}$ & $2.9 \pm 6.3 \mathrm{c}$ & $326.2 \pm 91.7 \mathrm{~d}$ & $0.000 \pm 0.01 \mathrm{a}$ & $226.6 \pm 64.2 \mathrm{~d}$ & $0.000 \pm 2.5 \mathrm{c}$ & $562.0 \pm 169.3 \mathrm{~d}$ \\
$10-20$ & $39.7 \pm 8.4 \mathrm{c}$ & $13.3 \pm 5.0 \mathrm{c}$ & $1135.9 \pm 72.6 \mathrm{c}$ & $0.000 \pm 0.01 \mathrm{a}$ & $603.4 \pm 50.8 \mathrm{c}$ & $2.5 \pm 2.0 \mathrm{c}$ & $1794.9 \pm 134.1 \mathrm{c}$ \\
$20-30$ & $162.7 \pm 8.5 \mathrm{~b}$ & $75.6 \pm 5.1 \mathrm{~b}$ & $2002.2 \pm 74.1 \mathrm{~b}$ & $0.000 \pm 0.01 \mathrm{a}$ & $1259.3 \pm 51.8 \mathrm{~b}$ & $13.6 \pm 2.0 \mathrm{~b}$ & $3513.6 \pm 136.7 \mathrm{~b}$ \\
$>30$ & $300.8 \pm 7.9 \mathrm{a}$ & $165.2 \pm 4.7 \mathrm{a}$ & $2903.5 \pm 68.6 \mathrm{a}$ & $0.030 \pm 0.01 \mathrm{a}$ & $1976.0 \pm 48.0 \mathrm{a}$ & $39.9 \pm 1.9 \mathrm{a}$ & $5385.6 \pm 126.6 \mathrm{a}$ \\
\hline
\end{tabular}

Means followed by the same letter in the same column are not significantly different at $P<0.05$ levels, mean \pm SEM 
Table 5 AMF spore density (100 $\mathrm{g}^{-1}$ of dry soil) across foot, middle, and upper slope position

\begin{tabular}{llllllll}
\hline Slope & Gigaspora & Scutellospora & Glomus & Sclerocystis & Acaulospora & Entrophospora & Sum \\
\hline Foot & $192.3 \pm 8.2 \mathrm{a}$ & $109.2 \pm 4.8 \mathrm{a}$ & $2578.0 \pm 66.0 \mathrm{a}$ & $0.006 \pm 0.01 \mathrm{a}$ & $1747.6 \pm 45.6 \mathrm{a}$ & $22.8 \pm 1.8 \mathrm{a}$ & $4650.1 \pm 122.9 \mathrm{a}$ \\
Middle & $133.8 \pm 9.0 \mathrm{~b}$ & $60.3 \pm 5.2 \mathrm{~b}$ & $1491.4 \pm 72.1 \mathrm{~b}$ & $0.021 \pm 0.01 \mathrm{a}$ & $947.4 \pm 49.9 \mathrm{~b}$ & $14.2 \pm 1.9 \mathrm{~b}$ & $2647.3 \pm 134.3 \mathrm{~b}$ \\
Upper & $96.8 \pm 9.2 \mathrm{c}$ & $42.8 \pm 5.4 \mathrm{c}$ & $1006.4 \pm 4.1 \mathrm{c}$ & $0.000 \pm 0.01 \mathrm{a}$ & $527.1 \pm 51.2 \mathrm{c}$ & $10.1 \pm 2.0 \mathrm{~b}$ & $1683.4 \pm 137.9 \mathrm{~b}$ \\
\hline
\end{tabular}

Means followed by the same letter in the same column are not significantly different at $P<0.05$ level, mean \pm SEM

richness increment from upper to down slope might be due to natural forces such as flood and wind. AM fungal spores rely on some forces that can move soil, such as strong winds, water, gophers, and worms, to migrate to a new location (David and Jeff 2010). Removal of surface soil layers mainly by water erosion decreased markedly both the number of propagules of AMF and the extent of mycorrhiza formation (Habte 1989; Powell 1981) thereby increase spore density and genera diversity down slope gradient.

All the age groups in both land uses exhibited all structures of AMF. The root colonization showed significant difference among the four age classes (Table 6). There was higher colonization in \% $\mathrm{HC}, \% \mathrm{MHC}, \% \mathrm{AC}$, and \% $\mathrm{VC}$ with increasing age from $<10$ years of age to $10-20$ years of age followed by 20-30 years of age, and the highest colonization was recorded in the age group $>30$ years old. The root colonization of Juniperus procera ranged from 59 to $79 \%$ and increased with the age of the tree (Amal and Hasnah 2012). Natural environment increased spore density and root colonization, indicating stability of ecosystems (Megan and Kirkegaard 2012).

Plant roots at the foot slope showed higher colonization compared to the plants at the middle and upper slope positions. Mycorrhizal hyphal colonization was significantly different between the foot slope and the other two slope position $(P<0.05)$. The interaction between age $\times$ land use and land use $\times$ elevation were sources of variation $(P=0.000)$ in root length colonization. Soil disturbance, degradation, and erosion can reduce levels of AMF propagules (Birhane et al. 2010; Carpenter et al. 2001; Brundrett et al. 1996). Vesicular, arbuscular, and hyphal colonization in soils of soybean plant root found colonized with AMF in 133 samples out of 167 samples examined at different

Table 6 Root colonization (\%) of AMF structures at four age groups of exclosure

\begin{tabular}{lllll}
\hline Age (year) & $H C$ & MHC & AC & VC \\
\hline$<10$ & $57.0 \pm 0.9 d$ & $39.9 \pm 1.0 d$ & $23.7 \pm 0.9 d$ & $10.3 \pm 0.9 d$ \\
$10-20$ & $65.8 \pm 0.7 \mathrm{c}$ & $55.5 \pm 0.8 \mathrm{c}$ & $37.3 \pm 0.7 \mathrm{c}$ & $23.3 \pm 0.7 \mathrm{c}$ \\
$20-30$ & $74.0 \pm 0.7 \mathrm{~b}$ & $68.9 \pm 0.8 \mathrm{~b}$ & $51.7 \pm 0.7 \mathrm{~b}$ & $39.7 \pm 0.7 \mathrm{~b}$ \\
$>30$ & $82.7 \pm 0.6 \mathrm{a}$ & $78.4 \pm 0.7 \mathrm{a}$ & $60.7 \pm 0.6 \mathrm{a}$ & $50.7 \pm 0.6 \mathrm{a}$
\end{tabular}

Means in the same column followed by same letter do not differ significantly at $P<0.05$, mean \pm SEM

$H C$ hyphal colonization, $M H C$ mycorrhizal hyphal colonization, $A C$ arbuscular colonization, $V C$ vesicular colonization slope positions (Bansode et al. 2014). Current distribution and density of AMF are the result of contemporary ecological processes that are under control of several factors such as altitude, soil chemical properties, soil disturbance, and above-ground vegetation (Sturmer and Siqueira 2011; Yang et al. 2010; Shukla et al. 2009).

\section{AMF in different woody plant species and their families}

All rhizosphere soil samples under each plant species generally displayed higher spore density as compared to other studies and were shown significant variation in spore density between plant species and their family (Table 7), though the grazing intensity varies with species. The highest spore density was found under Ficus vasta, Cordia africana, Ekeberrgia capensis, and Justicia schimperiana while Aloe vera, Opuntia ficus-indica, and Rumex nervosus exhibited the lowest spore density. Families of Acanthaceae, Boraginaceae, Meliaceae, and Moraceae had significantly higher spore density $100 \mathrm{~g}^{-1}$ dry soil while lowest spore counts were found in Aloeaceae, Cactaceae, and Polygonaceae rhizosphere soils. Low AMF spore count was reported by Muleta et al. (2008) for coffee and in a dry savannah wood land ecosystem under Acacia polyacantha rhizosphere soil (Yonas 2005).

Glomus was found in all the 32 plant families and 47 plant species followed by Acaulospora, Gigaspora, Scutellospora, Entrophospora, and the lowest found in Sclerocystis, respectively (Additional file 1: Table S1 and S2). Glomus is the most common AMF genus distributed globally and dominant in the tropical areas (Chaurasia 2000). Wide occurrence of Glomus in the present study suggested that the genus Glomus has wide ecological amplitude that is responsible for its adaptability and survival in different habitats and vegetation composition. The dominance of Glomus species has been reported from tree species in Ethiopia (Birhane et al. 2010; Wubet et al. 2003, 2009; Muleta et al. 2008). The variation in spore density between plants species may be due to differences in host trees which can be attributed to the type of AMF species associated with their respective hosts (Cardoso et al. 2003; Pringle and Bever 2002).

Typical structures like hyphae, arbuscules, and vesicles were observed in all tree species (Additional file 1: Table S3 and S4). This study was in agreement with Allen et al. (1998) and found all plant species to be colonized by AMF. There were a significant difference 
Table 7 AMF spore density (100 $\mathrm{g}^{-1}$ dry soil) and root colonization (\%) of plant species and their families

\begin{tabular}{|c|c|c|c|c|c|}
\hline \multicolumn{3}{|c|}{ AMF between plant species } & \multicolumn{3}{|c|}{ AMF between plant families } \\
\hline Plant species & Spore abundance & Root length colonization & Plant families & Spore abundance & Root colonization \\
\hline Abutilon longicuspe & $5173.6 \pm 194.9 \mathrm{bcde}$ & $81.7 \pm 5.5 \mathrm{abcdefg}$ & Acanthaceae & $12,463.0 \pm 396.2 a$ & $80.0 \pm 15.9$ abcdef \\
\hline Acacia decurrens & $2254.2 \pm 619.4 \mathrm{cdef}$ & $68.6 \pm 3.1 \mathrm{fghij}$ & Aloeaceae & $312.4 \pm 608.9 e$ & $57.5 \pm 3.1 \mathrm{ghi}$ \\
\hline Acacia etbaica & $2768.3 \pm 287.5 b c d e f$ & $73.0 \pm 1.4$ cdefghij & Anacardiaceae & $5505.4 \pm 586.7 \mathrm{bcd}$ & $92.1 \pm 3.0 \mathrm{abc}$ \\
\hline Acacia lahai & $3224.2 \pm 194.9 \mathrm{bcdef}$ & $83.3 \pm 5.5 \mathrm{abcdefg}$ & Apocynaceae & $6018.8 \pm 422.5 b c$ & $83.9 \pm 2.1 \mathrm{abcde}$ \\
\hline Acacia saligna & $3065.0 \pm 406.6 b c d e f$ & $72.2 \pm 2.0$ cdefghij & Asclepiadaceae & $2365.5 \pm 189.3 \mathrm{cde}$ & $85.5 \pm 11.2 \mathrm{abcd}$ \\
\hline Acokanthera schimpri & $6868.2 \pm 632.1 \mathrm{ab}$ & $90.5 \pm 3.1$ abcde & Berberidaceae & $2023.0 \pm 189.3 \mathrm{de}$ & $80.0 \pm 11.2 \mathrm{abcdef}$ \\
\hline Acacia seyal & $3893.2 \pm 272.6 b c d e f$ & $78.2 \pm 1.3 a b c d e f g h$ & Boraginaceae & $12,982.0 \pm 189.3 a$ & $100.0 \pm 11.2 \mathrm{a}$ \\
\hline Aloe vera & $312.4 \pm 607.3 f$ & $57.5 \pm 3.01 \mathrm{hij}$ & Buddleiaceae & $6031.0 \pm 1097.7 b c$ & $86.3 \pm 5.6 \mathrm{abcd}$ \\
\hline Berberis holstii & $2023.0 \pm 2181.6$ def & $80.0 \pm 10.9 a b c d e f g$ & Cactaceae & $173.7 \pm 677.5 \mathrm{e}$ & $56.9 \pm 3.4 \mathrm{hi}$ \\
\hline Becium grandiflorum & $2344.2 \pm 252.0 \mathrm{cdef}$ & $65.8 \pm 1.2 f g h i j$ & Capparidaceae & $2098.6 \pm 896.2 \mathrm{de}$ & $62.4 \pm 4.5 f g h i$ \\
\hline Buddleja polystachya & $5144.0 \pm 979.3 \mathrm{bcde}$ & $81.2 \pm 4.9 \mathrm{abcdefg}$ & Celastraceae & $2849.4 \pm 240.2 \mathrm{cde}$ & $68.4 \pm 1.2$ defghi \\
\hline Calpurinia aurea & $3318.8 \pm 360.0 \mathrm{bcdef}$ & $72.7 \pm 1.8$ cdefghij & Combretaceae & $5038.9 \pm 548.8 \mathrm{bcd}$ & $72.8 \pm 2.8$ cdefghi \\
\hline Cadaba farinose & $2098.6 \pm 894.0$ def & $62.4 \pm 4.5 \mathrm{ghij}$ & Cupressaceae & $2331.1 \pm 238.8 \mathrm{cde}$ & $76.4 \pm 1.2 \mathrm{bcdefgh}$ \\
\hline Carissa spinarum & $5339.3 \pm 565.4 \mathrm{bcde}$ & $78.6 \pm 2.8$ abcdefgh & Ebenaceae & $1769.8 \pm 211.7 \mathrm{de}$ & $62.2 \pm 1.0 f g h i$ \\
\hline Clutia lanceolata & $2024.0 \pm 3085.3 \mathrm{def}$ & $52.0 \pm 15.5 j$ & Ericaceae & $5330.5 \pm 189.3 \mathrm{bcd}$ & $73.50 \pm 11.2$ bcdefghi \\
\hline Combretum aculeatum & $5038.9 \pm 547.4 \mathrm{bcde}$ & $72.8 \pm 2.7$ cdefghij & Euphorbiaceae & $4839.5 \pm 457.7 \mathrm{bcd}$ & $77.0 \pm 2.3 a b c d e f g$ \\
\hline Cordia africana & $12,982.0 \pm 2181.6 a$ & $100.0 \pm 10.9 a$ & Fabaceae & $3185.5 \pm 148.6 \mathrm{bcde}$ & $73.3 \pm .7 \mathrm{bcdefghi}$ \\
\hline Croton macrostachyus & $5729.4 \pm 710.5$ bcde & $83.2 \pm 3.5 \mathrm{abcdefg}$ & Flacourtiaceae & $6738.6 \pm 1792.5 \mathrm{ab}$ & $96.3 \pm 9.1 a$ \\
\hline Cupressus lusitanica & $2433.6 \pm 710.5 \mathrm{cdef}$ & $86.7 \pm 3.5 \mathrm{abcdef}$ & Lamiaceae & $2380.7 \pm 251.0 \mathrm{cde}$ & $65.7 \pm 1.2$ efghi \\
\hline Diospyros abyssinica & $4893.0 \pm 2181.6 \mathrm{bcde}$ & $98.0 \pm 10.9 a$ & Loganiaceae & $5144.0 \pm 981.8 \mathrm{bcd}$ & $81.2 \pm 5.0 \mathrm{abcdef}$ \\
\hline Diplostigma canescens & $2365.5 \pm 2181.6 \mathrm{cdef}$ & $85.5 \pm 10.9 a b c d e f$ & Loranthaceae & $3533.0 \pm 189.3 \mathrm{bcde}$ & $85.5 \pm 11.2 \mathrm{abcd}$ \\
\hline Dovyalis abyssinica & $6738.6 \pm 1788.1 a b$ & $96.3 \pm 9.0 a$ & Malvaceae & $5173.6 \pm 1097.7 \mathrm{bcd}$ & $81.7 \pm 5.6 a b c d e f$ \\
\hline Dodonaea angustifolia & $3857.7 \pm 285.1 \mathrm{bcdef}$ & $76.2 \pm 1.4 a b c d$ efghi & Meliaceae & $10,498.0 \pm 1173.5 a$ & $80.8 \pm 6.0 \mathrm{abcdef}$ \\
\hline Ekeberrgia capensis & $10,498.0 \pm 170.5 a$ & $80.8 \pm 5.9 \mathrm{abcdefg}$ & Moraceae & $11,797.0 \pm 189.3 a$ & $88.5 \pm 11.2 \mathrm{abcd}$ \\
\hline Erica arborea & $5330.5 \pm 2181.6 \mathrm{bcde}$ & $73.5 \pm 10.9$ cdefghij & Myrtaceae & $2599.9 \pm 275.5 \mathrm{cde}$ & $69.2 \pm 1.4$ defghi \\
\hline Euphorbia abyssinica & $4213.3 \pm 596.0 \mathrm{bcdef}$ & $72.6 \pm 3.0$ cdefghij & Oleaceae & $6890.6 \pm 411.2 \mathrm{ab}$ & $92.9 \pm 2.1 \mathrm{ab}$ \\
\hline Eucalyptus camaldulensis & $2809.6 \pm 319.4 \mathrm{bcdef}$ & $69.6 \pm 1.6$ efghij & Oliniaceae & $3494.5 \pm 861.1 \mathrm{bcde}$ & $70.9 \pm 4.4$ defghi \\
\hline Eucalyptus globules & $2002.6 \pm 539.16$ def & $68.1 \pm 2.7 f g h i j$ & Polygonaceae & $264.0 \pm 694.2 \mathrm{e}$ & $55.1 \pm 3.5 i$ \\
\hline Euclea racemosa & $1769.8 \pm 211.2 \mathrm{ef}$ & $62.2 \pm 1.0 \mathrm{ghij}$ & Proteaceae & $2789.0 \pm 2189.3 \mathrm{cde}$ & $87.0 \pm 11.2 \mathrm{abcd}$ \\
\hline Ficus vasta & $11,797.0 \pm 2181.6 a$ & $88.5 \pm$ 10.9abcdef & Rosaceae & $7163.5 \pm 2189.3 a b$ & $100.0 \pm 11.2 \mathrm{a}$ \\
\hline Gravillea robusta & $2789.0 \pm 2181.6 \mathrm{bcdef}$ & $87.0 \pm 10.9 a b c d e f$ & Rubiaceae & $3013.0 \pm 2189.3 \mathrm{bcde}$ & $76.5 \pm 11.2$ bcdefgh \\
\hline Juniperus procera & $2318.1 \pm 252.8 \mathrm{cdef}$ & $75.0 \pm 1.2 \mathrm{bcdefghij}$ & Sapindaceae & $3857.7 \pm 285.8 \mathrm{bcde}$ & $76.2 \pm 1.4$ bcdefgh \\
\hline Justicia schimperiana & $12,463.0 \pm 3085.3 a$ & $80.0 \pm 15.5 \mathrm{abcdefg}$ & & & \\
\hline Maytenus arbutifolia & $2918.5 \pm 250.3 b c d e f$ & $68.6 \pm 1.2 \mathrm{fghij}$ & & & \\
\hline Maytenus senegalensis & $2094.7 \pm 827.7$ def & $65.8 \pm 4.1 \mathrm{fghij}$ & & & \\
\hline Nuxia congesta & $6031.0 \pm 194.9 \mathrm{bcd}$ & $86.3 \pm 5.5 \mathrm{abcdef}$ & & & \\
\hline Olea europaea & $6890.6 \pm 410.2 \mathrm{ab}$ & $92.9 \pm 2.0 \mathrm{abc}$ & & & \\
\hline Olinia rochetiana & $3494.5 \pm 858.9 \mathrm{bcdef}$ & $70.9 \pm 4.3$ defghij & & & \\
\hline Opuntia ficus indica & $173.7 \pm 675.8 f$ & $56.9 \pm 3.4 \mathrm{ij}$ & & & \\
\hline Osyris quadripartite & $3533.0 \pm 2181.6 \mathrm{bcdef}$ & $85.5 \pm 10.9 a b c d e f$ & & & \\
\hline Otostegia integrifolia & $2213.2 \pm 185.0 \mathrm{def}$ & $58.0 \pm 7.0 h i j$ & & & \\
\hline Psydrax schimperiana & $3013.0 \pm 2181.6 b c d e f$ & $76.50 \pm 10.9$ abcdefghi & & & \\
\hline
\end{tabular}


Table 7 AMF spore density (100 $\mathrm{g}^{-1}$ dry soil) and root colonization (\%) of plant species and their families (Continued)

\begin{tabular}{lll}
\hline Rhus glutinosa & $5137.0 \pm 692.5 \mathrm{bcde}$ & $91.1 \pm 3.5 \mathrm{abcd}$ \\
Rhus retinorrhoea & $6426.5 \pm 194.9 \mathrm{abc}$ & $94.8 \pm 5.56 \mathrm{ab}$ \\
Rosa abyssinica & $7163.5 \pm 2181.6 \mathrm{ab}$ & $100.0 \pm 10.9 \mathrm{a}$ \\
Rumex nervosus & $264.4 \pm 751.1 \mathrm{f}$ & $54.9 \pm 3.7 \mathrm{j}$ \\
Senna singueana & $2307.7 \pm 607.3 \mathrm{cdef}$ & $56.5 \pm 3.0 \mathrm{ij}$ \\
\hline
\end{tabular}

Means in the same column followed by same letter do not differ significantly at $P<0.05$ for spore abundance and root colonization of plants in highlands of Tigray. Mean \pm SEM

$(P=0.000)$ in root length colonization between plant species and their families (Table 7). Cordia africana, Diospyros abyssinica, Dovyalis abyssinica, and Rosa abyssinica showed significant difference while Clutia lanceolata and Rumex netvosus showed the lowest root length colonization. Boraginaceae, Flacourtiaceae, and Rosaceae were the plant families with higher root length colonization, and Polygonaceae recorded the least colonization and was similar with the results of Chanie and Assefa (2013). Root length colonization by AMF for six Acacia species were found from 56 to 80\% (Santhaguru and Sadhana 2000). The variation in the extent of root colonization could be related to the different preferences of the AMF to various species (Khade and Rodrigues 2009; David 2008) and mycorrhizal dependencies among plant species. The variations in plant species with relation to the degree of AMF colonization indicated that environmental factors influence the presence or absence of mycorrhizae and their colonization level (Alexander 1989) and such variation occur at genus and family levels (John 1980).

Acokanthera schimpri, Cordia africana, Diospyros abyssinica, Dovyalis abyssinica, Ekeberrgia capensis, Olea europaea, Rhus glutinosa, Rhus retinorrhoea, and Rosa abyssinica plant species had higher hyphal root colonization (Additional file 1: Table S3). Mycorrhizal hyphal colonization were higher in Cordia africana, Diospyros abyssinica, Dovyalis abyssinica, Olea europaea, Rhus glutinosa, Rhus retinorrhoea, and Rosa abyssinica plant species. Mycorrhizal hyphal colonization varied from high to low between different tree species (Chanie and Assefa 2013).

The four AMF structures were identified in all the 32 plants from all the study areas. Anacardiaceae, Boraginaceae, Flacourtiaceae, Meliaceae, Oleaceae, and Rosaceae showed higher hyphal colonization (Additional file 1: Table S4). Similarly, Anacardiaceae, Boraginaceae, Flacourtiaceae,
Oleaceae, and Rosaceae showed high mycorrhizal root colonization while high \% AC was recorded in Boraginaceae. High \% VC was observed in Rosaceae and Meliaceae. Recently, Burni and Hussain (2011) also reported variations in AMF root colonization in various members of Lamiaceae. Different edapho-climatic factors like soil type, nutritional status of soil, soil $\mathrm{pH}$, organic matter, soil moisture, rain fall, temperature, etc. may be responsible for variations in root colonization (Tanvir et al. 2011).

\section{AMF spore size}

High spore density was recovered for the spore groups with $50 \mu \mathrm{m}$ diameter followed by 100 and $300 \mu \mathrm{m}$ (Table 8). Acaulospora had higher spore density in 50 and $100 \mu \mathrm{m}$ diameter followed by Glomus while it was the most dominant in the $300 \mu \mathrm{m}$ diameter group. Gigaspora, Scutellospora, and Entrophospora were the third, fourth, and fifth dominants genera in 50 and $100 \mu \mathrm{m}$, respectively. Sclerocystis was the least dominant found only in 100 and $300 \mu \mathrm{m}$. Brundrett et al. (1996) reported AMF produce large asexual spores $(20-1000+\mu \mathrm{m}$ diameter). The fact that Acaulospora and Glomus are dominant genera in high lands of Tigray is related to their sporogenous characteristics. It has been found that Acaulospora and Glomus species usually produce more spores than Gigaspora and Scutellospora species in the same environment (Bever et al. 1996).

\section{Soil nutrients availability with increasing age of exclosures and slope position}

Soil chemical properties of exclosure soil were significantly higher than grazing land (Table 9). This result is supported by Mekuria (2010). Grazing impacts on soil properties depends on grazing intensity, with moderate grazing of 33 years compared with an ungrazed control resulted in higher $\mathrm{pH}$, available $\mathrm{P}$, and $\mathrm{Mg}$ (Ajorlo et al. 2011) and

Table 8 Spore density ( $100 \mathrm{~g}^{-1}$ of dry soil) and types of genera at different spore size $(\mu \mathrm{m})$ categories

\begin{tabular}{llllllll}
\hline Spore size $(\mu \mathrm{m})$ & Gigaspora & Scutellospora & Glomus & Sclerocystis & Acaulospora & Entrophospora & Sum \\
\hline $50 \mu \mathrm{m}$ & $87.8 \pm 2.1 \mathrm{a}$ & $45.2 \pm 1.2 \mathrm{a}$ & $263.2 \pm 5.3 \mathrm{a}$ & $0.000 \pm 0.003 \mathrm{a}$ & $626.1 \pm 11.9 \mathrm{a}$ & $10.9 \pm 0.4 \mathrm{a}$ & $1784.2 \pm 32.0 \mathrm{a}$ \\
$100 \mu \mathrm{m}$ & $48.2 \pm 2.1 \mathrm{~b}$ & $24.2 \pm 1.2 \mathrm{~b}$ & $270.4 \pm 5.3 \mathrm{a}$ & $0.007 \pm 0.003 \mathrm{a}$ & $389.1 \pm 11.9 \mathrm{~b}$ & $3.5 \pm 0.4 \mathrm{~b}$ & $1079.1 \pm 32.0 \mathrm{~b}$ \\
$300 \mu \mathrm{m}$ & $8.8 \pm 2.1 \mathrm{c}$ & $4.1 \pm 1.2 \mathrm{c}$ & $129.9 \pm 5.3 \mathrm{~b}$ & $0.002 \pm 0.003 \mathrm{a}$ & $109.4 \pm 11.9 \mathrm{c}$ & $1.8 \pm 0.4 \mathrm{c}$ & $254.2 \pm 32.0 \mathrm{c}$ \\
\hline
\end{tabular}

Means in the same column followed by same letter do not differ significantly at $P<0.05$, mean \pm SEM 
Table 9 Soil properties in exclosures and adjacent grazing lands with increasing age of exclosures and slope position

\begin{tabular}{lllllllll}
\hline & & $\mathrm{pH}$ & $\mathrm{EC}(\mathrm{msm})$ & $\mathrm{P}(\mathrm{ppm})$ & $\mathrm{K}(\mathrm{ppm})$ & $\mathrm{N}(\%)$ & $\mathrm{OC}(\%)$ & $\mathrm{OM}(\%)$ \\
\hline Land uses & Exclosure & $7.7 \pm 0.03 \mathrm{a}$ & $15.8 \pm 0.38 \mathrm{a}$ & $9.1 \pm 0.45 \mathrm{a}$ & $8.8 \pm 0.2 \mathrm{a}$ & $0.5 \pm 0.01 \mathrm{a}$ & $1.7 \pm 0.05 \mathrm{a}$ & $2.9 \pm 0.09 \mathrm{a}$ \\
& Grazing land & $7.2 \pm 0.03 \mathrm{~b}$ & $9.4 \pm 0.38 \mathrm{~b}$ & $2.9 \pm 0.45 \mathrm{~b}$ & $3.7 \pm 0.29 \mathrm{~b}$ & $0.2 \pm 0.01 \mathrm{~b}$ & $0.3 \pm 0.05 \mathrm{~b}$ & $0.5 \pm 0.09 \mathrm{~b}$ \\
Age groups & $<10$ & $7.2 \pm 0.05 \mathrm{c}$ & $10.4 \pm 0.64 \mathrm{~b}$ & $2.2 \pm 0.67 \mathrm{c}$ & $3.85 \pm 0.49 \mathrm{c}$ & $0.3 \pm 0.02 \mathrm{~b}$ & $0.4 \pm 0.11 \mathrm{c}$ & $0.7 \pm 0.19 \mathrm{c}$ \\
& $10-20$ & $7.4 \pm 0.05 \mathrm{~b}$ & $11.9 \pm 0.64 \mathrm{~b}$ & $5.7 \pm 0.67 \mathrm{~b}$ & $6.1 \pm 0.49 \mathrm{~b}$ & $0.4 \pm 0.02 \mathrm{~b}$ & $0.95 \pm 0.11 \mathrm{~b}$ & $1.6 \pm 0.19 \mathrm{~b}$ \\
& $20-30$ & $7.6 \pm 0.05 \mathrm{ab}$ & $12.4 \pm 0.64 \mathrm{~b}$ & $6.16 \pm 0.67 \mathrm{~b}$ & $6.7 \pm 0.49 \mathrm{ab}$ & $0.4 \pm 0.02 \mathrm{ab}$ & $1.2 \pm 0.11 \mathrm{ab}$ & $2.1 \pm 0.19 \mathrm{ab}$ \\
& $>30$ & $7.7 \pm 0.05 \mathrm{a}$ & $15.8 \pm 0.64 \mathrm{a}$ & $9.9 \pm 0.67 \mathrm{a}$ & $8.3 \pm 0.50 \mathrm{a}$ & $0.5 \pm 0.02 \mathrm{a}$ & $1.4 \pm 0.11 \mathrm{a}$ & $2.5 \pm 0.19 \mathrm{a}$ \\
\multirow{3}{*}{ Slope position } & Foot & $7.7 \pm 0.04 \mathrm{a}$ & $14.2 \pm 0.58 \mathrm{a}$ & $7.2 \pm 0.66 \mathrm{a}$ & $6.6 \pm 0.47 \mathrm{a}$ & $0.4 \pm 0.02 \mathrm{a}$ & $1.2 \pm 0.10 \mathrm{a}$ & $2.1 \pm 0.18 \mathrm{a}$ \\
& Middle & $7.5 \pm 0.04 \mathrm{~b}$ & $12.4 \pm 0.58 \mathrm{ab}$ & $5.7 \pm 0.66 \mathrm{a}$ & $6.3 \pm 0.4 \mathrm{a}$ & $0.4 \pm 0.02 \mathrm{~b}$ & $1.0 \pm 0.10 \mathrm{ab}$ & $1.7 \pm 0.18 \mathrm{ab}$ \\
& Upper & $7.3 \pm 0.04 \mathrm{~b}$ & $11.2 \pm 0.58 \mathrm{c}$ & $5.1 \pm 0.66 \mathrm{a}$ & $5.7 \pm 0.46 \mathrm{a}$ & $0.3 \pm 0.020 \mathrm{~b}$ & $0.8 \pm 0.10 \mathrm{~b}$ & $1.4 \pm 0.18 \mathrm{~b}$ \\
\hline
\end{tabular}

Means in the same column followed by the same letter do not differ significantly at $P<0.05$, mean \pm SEM

available $\mathrm{P}$, total $\mathrm{N}, \mathrm{Ca}, \mathrm{Mg}$, and $\mathrm{K}$ decreased after 1.5 years of heavy grazing compared with an ungrazed control in a tropical pasture. Soil chemical properties at older age exclosure had better $\mathrm{pH}, \mathrm{EC}, \mathrm{P}, \mathrm{N}, \mathrm{K}, \mathrm{OC}$, and $\mathrm{OM}$ than the three young age groups of exclosures. Availability of soil nutrients decreased with decreasing age of exclosure. Foot slope had better soil chemical properties than the middle and upper slope (Table 9). EC showed significantly higher in foot slope followed by middle and upper slope respectively which is in agreement with Mekuria (2010).

\section{Correlation between AMF and availability of soil nutrients}

Spore density had positively correlated with the soil parameters (Table 10) which is in agreement with the studies of Minal and Anil (2012) found a significant positive correlation with $\mathrm{pH}(r=0.85, P<0.01)$ and organic carbon $(r=0.68, P<0.05)$. Similarly, Arpita et al. (2012) found root colonization were positively correlated with \% $\mathrm{OC}, \mathrm{pH}$, available nitrogen, and available phosphorus but negatively correlated with available potassium. Spore densities were positively correlated with all soil parameters except soil pH. Don-Rodrigue et al. (2013) and Amal et al. (2013) also found positive correlation of soil properties with AMF.

Table 10 Pearson correlation between soil parameters and AMF spore density (100 $\mathrm{g}^{-1}$ of dry soil) and colonization (\%)

\begin{tabular}{lllllll}
\hline \multirow{2}{*}{$\begin{array}{l}\text { AMF } \\
\text { parameters }\end{array}$} & \multicolumn{6}{l}{ Soil parameters } \\
\cline { 2 - 6 } & $\mathrm{EC}(\mathrm{msm})$ & $\mathrm{P}(\mathrm{ppm})$ & $\mathrm{K}(\mathrm{ppm})$ & $\mathrm{N}(\%)$ & $\mathrm{OC}(\%)$ & $\mathrm{OM}(\%)$ \\
\hline Spore density & $0.888^{*}$ & $0.822^{*}$ & $0.897^{*}$ & $0.860^{*}$ & $0.904^{*}$ & $0.904^{*}$ \\
$\mathrm{HC}$ & $0.630^{*}$ & $0.638^{*}$ & $0.720^{*}$ & $0.720^{*}$ & $0.737^{*}$ & $0.737^{*}$ \\
MHC & $0.678^{*}$ & $0.708^{*}$ & $0.758^{*}$ & $0.731^{*}$ & $0.784^{*}$ & $0.784^{*}$ \\
$\mathrm{AC}$ & $0.599^{*}$ & $0.653^{*}$ & $0.673^{*}$ & $0.647^{*}$ & $0.708^{*}$ & $0.708^{*}$ \\
VC & $0.628^{*}$ & $0.692^{*}$ & $0.685^{*}$ & $0.645^{*}$ & $0.716^{*}$ & $0.716^{*}$ \\
\hline
\end{tabular}

HC hyphal colonization, $M H C$ mycorrhizal hyphal colonization, $A C$ arbuscular colonization, VC vesicular colonization

${ }^{*}$ Correlation is significant at the 0.05 level

\section{Conclusions}

AMF spore density and root colonization were higher in exclosures as compared to grazing land and increased with age of exclosures. Foot slope had greater spore density and root colonization than mid and upper slopes. Soil chemical properties showed significant difference and were highest in the exclosure, oldest age of exclosure and foot slope followed by grazing land, youngest age of exclosure and upper slope. AMF spore density and root colonization were significantly positively correlated to soil chemical properties.

\section{Additional file}

Additional file 1: Table S1. AMF spore density $\left(100 \mathrm{~g}^{-1}\right.$ dry soil) and genera by plant species (Mean \pm SEM). Table S2. AMF spore density (100 g ${ }^{-1} \mathrm{dry}$ soil) and genera by plant families. (Mean \pm SEM). Table S3. AMF root colonization (\%) of different plant species. HC: hyphal colonization, MHC: mycorrhizal hyphal colonization, AC: arbuscular colonization, VC: vesicular colonization. Mean \pm SEM. Table S4 AMF root colonization (\%) of plant families in highlands of Tigray. HC: hyphal colonization, MHC: mycorrhizal hyphal colonization, AC: arbuscular colonization, VC: vesicular colonization. Mean \pm SEM. (DOCX $38 \mathrm{~kb})$

\section{Acknowledgements}

We are grateful to the three anonymous referees for constructive comments on an earlier version of this manuscript. We want to thank the departments of LaRMEP (Forestry, Physical and Chemical labs), chemistry (Organic, Analytical and Physical labs), and biology (Aquatic ecology and Micro-biology labs) for their permission to do laboratory analysis in their respective laboratories.

\section{Funding}

The data collection of the study was supported by the Swedish International Development Authority (SIDA) under the Agroecology and Sustainable development project in Mekelle University. The write-up was funded by the steps towards sustainable forest management with the local communities in Tigray, Northern Ethiopia (ETH 13/0018) project funded by NORAD under the NORHED programme.

\section{Authors' contributions}

$\mathrm{EB}$ and KMG generated the idea, designed the study, carried out the experiment works, conducted the sample collection and laboratory analysis, collected and analyzed the data, and wrote the manuscript. TD participated in its design and coordination and helped to draft the manuscript. MH and NS provided the statistical assistance and revised the manuscript draft. All authors read and approved the final manuscript. 


\section{Competing interests}

The authors declare that they have no competing interests.

\section{Publisher's Note}

Springer Nature remains neutral with regard to jurisdictional claims in published maps and institutional affiliations.

\section{Author details}

'Department of Land Resources Management and Environmental protection, Mekelle University, PO Box 231, Mekelle, Ethiopia. Faculty of Environmental Sciences and Natural Resource Management, Norwegian University of Life Sciences, PO Box 5003, 1432 Ås, Norway. ${ }^{3}$ Department of Natural Resource Economics and Management, Mekelle University, PO Box 231, Mekelle, Ethiopia.

Received: 18 May 2017 Accepted: 29 August 2017

\section{Published online: 18 September 2017}

\section{References}

Abbott LK, Robson AD (1991) Factors influencing the occurrence of vesiculararbuscular mycorrhizas. Agric Ecosyst Environ 35:121-150

Aggarwal A, Kadian N, Tanwar A, Yadav A, Gupta KK (2011) Role of arbuscular mycorrhizal fungi (AMF) in global sustainable development. J Appl Nat Sci 3: 340-351

Ajorlo M, Abdullah R, Hanif AHM, Halim RA, Yusoff MK (2011) Impacts of livestock grazing on selected soil chemical properties in intensively managed pastures of Peninsular Malaysia. J Trop Agric Sci 34:109-121

Alexander IJ (1989) Mycorrhizas in tropical Forests. In: Proctor (ed.), Mineral nutrients in troppical Forests and Savannahs ecosystems. pp 169-188 Oxford: Blackwell.

Allen EB, Rincon E, Allen MF, Perezjimenez A, Huante P (1998) Disturbance and seasonal dynamics of mycorrhizae in a tropical deciduous forest in Mexico. Biotropica 30:261-274Alexander IJ (1989) Mycorrhizas in tropical forests In Proctor J (ed) Mineral nutrients in tropical forest and savannah ecosystems. Oxford: Blackwell, pp169-188

Amal AM, AL-Ghamdi, Hasnah MJ (2012) Interaction between Arbuscular Mycorrhiza and heavy metals in the rhizosphere and roots of Juniperus procera. Int J Agric Biol 14:69-74

Amal AM, AL-Ghamdi, Hasnah MJ (2013) Interaction between soil textura components, flavonoids in the roots and mycorrhizal colonization in Juniperus procera in Saudi Arabia. Afr J Microbiol Res 7:996-1001

Anwar QMK, Jalaluddin M (1991) The quantitative distribution of VAM spore population in soil of the wheat fields of districts of Sindh. Pak J Bot 25:54-60

Arpita P, Mall TP, Singh RP, Singh RB (2012) Mycorrhizal population of Indian mustard at different location of district Baharaich, Uttar Pradesh. Int Multidiscip Res J 2:45-49

Asmelash F, Bekele T, Birhane E (2016) The potential role of arbuscular mycorrhizal fungi in the restoration of degraded lands. Front Microbiol 7: 1095. https://doi.org/10.3389/fmicb.2016.01095

Bai G, Bao YY, Du GX, Qi YL (2013) Arbuscular mycorrhizal fungi associated with vegetation and soil parameters under rest grazing management in a desert steppe ecosystem. Mycorrhiza 23:289-301

Bansode SA, Sawant VS, Bhale UN (2014) Reclamation of degraded land through pond sedimentary soil and impact of biomass production and arbuscular mycorrhizal fungal (AMF) status of soybean field. IJBAF 2:33-41

Bekele TA (2007) Useful trees of Ethiopia: identification, propagation and management in 17 agroecological zones. RELMA in ICRAF Project, Nairobi, p 552

Bever JD, Morton JB, Antonovics J, Schultz PA (1996) Host-dependent sporulation and species diversity of arbuscular mycorrhizal fungi in a mown grassland. J Ecol 84:71-82

Birhane E, Aregawi K, Giday K (2017) Changes in arbuscular mycorrhiza fungi spore density and root colonization of woody plants in response to exclosure age and slope position in the highlands of Tigray, Northern Ethiopia. J Arid Environ 142:1-10

Birhane E, Demel T, Barklund P (2006) Actual and potential contribution of exclosures to enhance biodiversity of woody species in the drylands of Eastern Tigray. J Drylands 1:134-147

Birhane E, Kuyper TW, Sterck FJ, Bongers F (2010) Arbuscular mycorrhizal associations in Boswellia papyrifera (frankincense-tree) dominated dry deciduous woodlands of Northern Ethiopia. For Ecol Manag 260:2160-2169
Borie F, Rubio R, Morales A (2008) Arbuscular mycorrhizal fungi and soil aggregation. Revista Ciencia Del Suelo Y Nutrición Vegetal 8:9-18

Bremmer JM, Mulvaney CS (1982) Nitrogen total. In Page AL (Ed) Methods of Soil Analysis, part 2 chemical and microbiological properties ASA monograph, number 9. Soil Science Society of America, Madison, WI, USA, 595-624

Brundrett MC, Bougher N, Dell B, Grove T, Malajczuk N (1996) Working with mycorrhizas in forestry and agriculture. ACIAR Monograph 32. Australian Center for International Agricultural Research, Canberra

Brundrett MC, Piche Y, Peterson L (1994) A new method for observing the morphology of VAM.Can J Bot. 62:2128-2134.

Burni T, Hussain F (2011) Diversity in arbuscular mycorrhizal morphology in some medicinal plants of family Lamiaceae. Pak J Bot 43:1789-1792

Burni T, Iftikhar S, Jabeen M, Zainab SB (2009) Diversity of VA (Vesicular Arbuscular) fungi in some weeds of cauliflower fields of Peshawar, Pakistan. Pak J PI Sci 15:59-67

Burni T, Illahi I (2004) Quantification and correlation of VAM spores with the soil characteristics of wheat fields of NWFP. Pak J PI Sci 10:139-144

Cardoso IM, Boddington C, Janssen BH, Oenema O, Kuyper TW (2003) Distribution of mycorrhizal fungal spores in soils under agroforestry and monocultural coffee systems in Brazil. Agrofor Syst 58:33-43

Carpenter FL, Mayorga SP, Quintero EG, Schroeder M (2001) Land-use and erosion of a Costa Rican Ultisol affect soil chemistry, mycorrhizal fungi and early regeneration. For Ecol Manag 144:1-17

Chanie T, Assefa F (2013) Arbuscular mycorrhizal fungi associated with shade trees and Coffea arabica L. in a coffee-based agroforestry system in Bonga, Southwestern Ethiopia. Afrika Focus 26:111-131

Chaurasia B (2000) Ecological study of tropical forest trees with special reference to vesicular arbuscular mycorrhizal (VAM) association. PhD Thesis. Dr. H. S. Gour University, India, p 172

Cheng J, Wu GL, Zhao LP, Li Y, Li W, Cheng JM (2011) Cumulative effects of 20year exclusion of livestock grazing on above and belowground biomass of typical steppe communities in arid areas of the Loess Plateau, China. Plant Soil Environ 57:40-44

Chris P (2010) Diversity and abundance of arbuscular-mycorrhizal fungus spores in tropical Forest and pasture. Biotropica 32:734-750

David B (2008) Effects of Alliaria petiolata (garlic mustard; brassicaceae) on mycorrhizal colonization and community structure in three herbaceous plants in a mixed deciduous forest. Am J Bot 95:1416-1425

David I, Jeff S (2010) Mycorrhizae in the Alaska Landscape. www.uaf.edu/ces. 910/DI-JS/

Descheemaeker K, Muys G, Nyssen J, Poesen J, Raes D, Mitiku H, Deckers J (2006a) Litter production and organic matter accumulation in exclosures of the Tigray highlands, Ethiopia. For Ecol Manag 233:21-35

Descheemaeker K, Nyssen J, Rossi J, Poesen J, Mitiku H, Moeyersons J, Deckers J (2006b) Sediment deposition and pedogenesis in exclosures in the Tigray Highlands, Ethiopia. Geoderma 132:291-314

Don-Rodrigue RBV, Jacob N, Jean-Marc DS, Beaulys F, Jesus AA, Marie-Stephanie AK, Seydou O, Sebastien N, Adolphe Z (2013) Abundance and diversity of Arbuscular mycorrhizal fungal (AMF) communities associated with cassava (Manihot esculenta Crantz) rhizosphere in Abengourou, East Côte d'Ivoire. J Ecol Nat Environ 5:360-370

EMA (2015). Ethiopian meteorological service agency report of Ethiopian meteorological service. Birhan and Selam Printing Press, Addis Ababa, Ethiopia

Eom AH, Wilson GWT, Hartnett DC (2001) Effects of ungulate grazers on Arbuscular mycorrhizal sym- biosis and fungal community structure in tallgrass prairie. Mycologia 92:233-242

Frank DA, Kuns MM, Guido DR (2002) Consumer control of grassland plant production. Ecology 83:602-606

Frank DA, McNaughton SJ (1993) Evidence for the promotion of aboveground grassland production by native large herbivores in Yellowstone National Park. Oecologia 96:157-161

Gange AC (2007) Insect-mycorrhizal interactions: patterns, processes, and consequences. In: Ohgushi T, Craig TP, Price PW (eds) Ecological communities: plant mediation in indirect interaction webs. Cambridge University Press, London, pp 124-143

Gee GW, Bauder JW (1982) Particle size analysis. In: Klute A (ed) Methods of Soi Analysis, Part 1 Physical and Mineralogical Methods. ASA Monograph number 9, Madison, WI, USA, pp 383-411

Gehring CA, Whitham TG (2002) Mycorrhizae herbivore interactions: population and community consequences. In: van der Heijden MGA, Sanders IR (eds) Mycorrhizal Ecology. Springer, Berlin, pp 295-320 
Girmay G, Singh BR, Nyssen J, Borrosen T (2009) Runoff and sedimentassociated nutrient losses under different land uses in Tigray, Northern Ethiopia. J Hydrol 376:70-80

Habte M (1989) Impact of simulated erosion on the abundance and activity of indigenous vesicular arbuscular mycorrhizal endophytes in an oxisol. Biol Fertil Soils 7:164-167

Hiernaux P, Bielders CL, Valentin C, Bationo A, Fernandez-Rivera S (1999) Effects of livestock grazing on physical and chemical properties of sandy soils in Sahelian rangelands. J Arid Environ 41:231-245

Inga H, Sue E (1989) Flora of Ethiopia Pittosporaceae to Araliaceae volume 3. Addis Ababa University press, Addis Ababa, Ethiopia

Inga H, Sue E, Sileshi N (2003) Flora of Ethiopia and Eritrea Apiaceae to Dipsacaceae Volume 4, Part 1. Addis Ababa University press, Addis Ababa, Ethiopia

Jeddi K, Chaieb M (2010) Changes in soil properties and vegetation following livestock grazing exclusion in degraded arid environments of South Tunisia. Flora 205:184-189

John St TV (1980) A survey of mycorrhizal infection in an Amazonian rain forest. Acta Amazon 10:527-533

Khade SW, Rodrigues BF (2009) Arbuscular Mycorrhizal fungi associated with varieties of Carica papaya L. In tropical agro-based ecosystem of Goa India. Trop Subtrop Agroecosyst 10:369-381

Manoharachary C, Sridhar K, Reena S, Alok A, Suryanarayanan TS, Seema R, Johri BN (2005) Fungal biodiversity: distribution, conservation and prospecting of fungi from India. Curr Sci 89:1-10

Mathimaran N, Ruh R, Jama B, Verchot L, Jansa J (2007) Impact of agricultural management on arbuscularmycorrhizal fungal communities in Kenyan Ferralsol. Agric Ecosyst Environ 119:22-32

McNaughton SJ (1979) Grazing as an optimization process: grass ungulate relationships in the Serengeti. Am Nat 113:691-703

Megan HR, Kirkegaard J (2012) The agronomic relevance of arbuscular mycorrhizas in the fertility of Australian extensive cropping systems. Agric Ecosyst Environ 163:37-53

Mekuria W (2010) Effectiveness of Exclosures to restore ecosystem carbon stock and vegetation in the highlands of Tigray, Northern Ethiopia. Sierke Verlag publing, Gottingen

Mekuria W, Veldkamp E, Haile M, Gebrehiwot K, Muys B, Nyssen J (2009) Effectiveness of exclosures to control soil erosion and local community perception on soil erosion in Tigray, Ethiopia. Afr J Agric Res 4:365-377

Mekuria W, Veldkamp E, Haile M, Nyssen J, Muys B, Gebrehiwot K (2007) Effectiveness of exclosures to restore degraded soils as a result of overgrazing in Tigray, Ethiopia. J Arid Environ 69:270-284

Mengistu T, Demel T, Håkan H, Yonas Y (2005) The role of enclosures in the recovery of woody vegetation in degraded dryland hillsides of central and northern Ethiopia. J Arid Environ 60:259-281

Miller RM, Jastrow JD (1992) The application of VA mycorrhizae to ecosystem restoration and reclamation. In: Allen MF (ed) Mycorrhizal functioning. Chapman and Hall, Ltd, London, England, pp 438-467

Minal T, Anil V (2012) Mycorrhizae at polluted site of western rajasthan. Int J Plant Anim Environ Sci 2:325-487

Mridha MAU, Dhar PP (2007) Biodiversity of Arbuscular Mycorrhizal colonization and spore population in different Agroforestry trees and crop species growing in Diana-jpur Bangladesh. J For Res 18:91-96

Muleta D, Assefa F, Nemomissa S, Granhall U (2008) Distribution of Arbuscular mycorrhizal fungi spores in soils of smallholder agroforestry and monocultural coffee systems in southwestern Ethiopia. Biol Fertil Soils 44:653-659

Muthukumar T, Udaiyan K (2000) Arbuscular mycorrhizas of plants growing in the western Ghats region, southern India. Mycorrhiza 9:297-313

Nedessa B, Ali J, Nyborg I (2005) Exploring ecological and socio-economic issues for the improvement of area enclosure management. A case study from Ethiopia. DCG Report 38. DCG, Addis Ababa, Ethiopia

Olsen SR, Sommers LE (1982) Phosphorus. In: Page AL (ed) Methods of Soil Analysis, Part 2: Chemical and Microbiological Properties. ASA Monograph, vol 9, pp 403-430

Pande M, Tarafdar JF (2004) Arbuscular Mycorrhizal fungal diversity in Neem based Agroforestry systems in Rajistan. Appl Soil Ecol 26:233-241

Panwar J, Tarafdar JC (2006) Distribution of three endangered medicinal plant species and their colonization with arbuscular mycorrhizal fungi. J Arid Environ 65:337-350

Powell CL (1981) Inoculation of barley with efficient mycorrhizal fungi stimulates seed yield. Plant Soil 59:487-489
Pringle A, Bever JD (2002) Divergent phenologies may facilitate the coexistence of arbuscular mycorrhizal fungi in a North Carolina Grassland. An J Bot 89: 1439-1446

Ranst Van E, Verloo M, Demeyer A, Pauwels JM (1999) Manual for the soil chemistry and fertility laboratory: analytical methods for soils and plants, equipments and management of consumables. University of Gent, Belgium

Rillig MC (2004) Arbuscular mycorrhizae, glomalin, and soil aggregation. Can J Soil Sci 84:355-363

Santhaguru K, Sadhana B (2000) Vesicular-Arbuscular Mycorrhizal status of acacia species from Madurai district. Ann For 8:266-269

Santos-González JC, Finlay RD, Tehler A (2007) Seasonal dynamics of Arbuscular mycorrhizal fungal communities in roots in a seminatural grassland. Appl Environ Microbiol 73:5613-5623

Schalamuk S, Velazquez S, Chidichimo H, Cabello M (2006) Fungal spore diversity of arbuscular mycorrhizal fungi associated with spring wheat: effects of tillage. Mycologia 98:16-22

Sharma D, Kapoor R, Bhaytnagar AR (2009) Differential growth response of Curculigo orchoides to native AMF communities varying in number and fungal components. Eur J Soil Biol 45:328-333

Shukla A, Kumar A, Jha A, Chaturvedi OP, Prasad R, Gupta A (2009) Effects of shade on Arbuscular mycorrhizal colonization and growth of crops and tree seedlings in Central India. Agrofor Syst 76:95-109

Sturmer SL, Siqueira JO (2011) Species richness and spore abun-dance of arbuscular mycorrhizal fungi across distinct land uses in Western Brazilian Amazon. Mycorrhiza 21:255-267

Sue E, Mesfin T, Inga H (1995) Flora of Ethiopia and Eritrea volume 2, Canellaceae to Euphorbiaceae part 2. Addis Ababa university press, Addis Ababa

Sue E, Mesfin T, Sebsebe D, Inga H (2000) Flora of Ethiopia \& Eritrea Part 1 Magnoliaceae to FlacourtiaceaeVolume 2. Addis Ababa university press, Addis Ababa

Tadesse G, Penden D (2002) Livestock grazing impact on vegetation, soil and hydrology in a tropical highland watershed. Proceedings of MoWR/ EARO/ IWMI/ILRI, International Workshop held at ILRI, Addis Ababa, Ethiopia 2-4 December

Tanvir B, Hussain F, Sharief M (2011) Arbuscular mycorrhizal fungi (AMF) associated with the rhizosphere of mentha arvensis I., and m.longifolia huds. Pak J Bot 43:3013-3019

Vyas D, Gupta RK (2014) Effect of edaphic factors on the diversity of VAM fungi. Trop Plant Res 1:14-25

Wang FY, Zao YS (2008) Biodiversity of Arbuscular Mycorrhizal fungi in China: a review. Adv Environ Biol 2:31-39

Wilson J, Ingleby K, Mason PA, Ibrahim K, Lawson GJ (1992) Long-term changes in vesicular arbuscularmycorrhizal spore population in Terminalia plantations in Côte d'Ivoire. In: Read DJ, Lewis DH, Fitter AH, Alexander IJ (eds) Mycorrhizas in ecosystems. CAB International, Oxon, UK, pp 268-275

WRB (2006) World reference base for soil resources. 2nd edition. World Soil Resources Reports No. 103. FAO, Rome

Wubet T, Kottke I, Teketay D, Oberwinkler F (2003) Mycorrhizal status of indigenous trees in dry Afromontane forests of Ethiopia. For Ecol Manag 179:387-399

Wubet T, Kottke I, Teketay D, Oberwinkler F (2009) Arbuscular mycorrhizal fungal community structures differ between co-occurring tree species of dry Afromontane tropical forest, and their seedlings exhibit potential to trap isolates suitable for reforestation. Mycol Progress 8:317-328

Yami M, Gebrehiwot K, Stein M, Mekuria W (2007) Impact of area enclosures on density and diversity of large wild mammals: the case of may Ba'ati, Douga Tembien District, Central Tigray, Ethiopia. East Afr J Sci 1:55-68

Yang FY, Li GZ, Zhang DE, Christie P, Li XL, Gai JP (2010) Geographical and plant genotype effects on the formation of arbuscular mycorrhiza in Avena sativa and Avena nuda at different soil depths. Biol Fertil Soil 46:435-443

Yonas Y (2005) Symbiotic and phenotypic characteristics of root nodule bacteria and Arbuscular Mycorrhizal fungi infecting Acacia polyacantha growing in Ghibe wooded grasslands. MSc. thesis. Addis Ababa University, Ethiopia

Zhao ZW, Wang GH, Yang L (2003) Biodiversity of arbuscular mycorrhizal fungi in a tropical rainforest of Xishuangbanna, southwest China. Fungal Divers 13:233-242 